\title{
SOCIAL PROTEST AND THE RISE OF THE NOVEL
}

\section{PROTESTA SOCIAL Y EL SURGIMIENTO DE LA NOVELA}

\author{
Gassim H. Dohal ${ }^{1} *$ iD. \\ 1. Independent Researcher, Gizan, Saudi Arabia.dr_waitme@hotmail.com \\ *Corresponding author: Gassim H. Dohal, email: dr_waitme@hotmail.com
}

\begin{abstract}
The early eighteenth century witnessed the early development of the dominant literary form of modern times, the novel. The novel emerged as a form with structure and interplay between individuals and their relationships to society. As a new form, the novel tends to make some significant, critical, and social statements about the society. Hence, the novel is used to create a new environment that is related to life and people. Indeed, this is what makes the novel appeal to readers as a new genre. Novelists either try to deal with daily social problems that happen in the lives of people or pretend that they are telling real stories.

It is not surprising to find that Daniel Defoe molds his Robinson Crusoe (1719)on a real story while Samuel Richardson in Pamela (1740) turns out to be didactic to meet the needs of the growing numbers of female readers. On his part, Henry Fielding tries to expose his society to the readers in his masterpiece The History of Tom Jones, a Foundling (1749); from now on Tom Jones. Accordingly, the novel becomes popular at this time because it has something relevant to the mob; it deals with their social life, and they can identify themselves with its characters in the actual daily life. Through Tom Jones, Fielding presented "a true and realistic picture of human nature" (Kettle, 71). As long as its main concern is the existing society, novelists feel so involved that their criticism becomes direct, frank, and effective. My paper deals with these concerns as depicted in the novels mentioned above.
\end{abstract}

Keywords: novel; social protest; Crusoe; Pamela; Tom Jones.

Cómo citar:

Dohal, Gassim H. (2021). Social protest and the rise of the novel. Revista

de Investigaciones Universidad del Quindio, 33(2), 109-114. https://

doi.org/10.33975/riuq.vol33n2.561

Información del artículo:

Recibido: 21 julio 2021; Aceptado: 20 agosto 2021

Revista de Investigaciones Universidad del Quindío,

33(2), 109-114; 2021.

ISSN: 1794-631X e-ISSN: 2500-5782

Esta obra está bajo una licencia Creative Commons Atribución-

NoComercial-SinDerivadas 4.0 Internacional. 


\section{RESUMEN}

El comienzo del siglo XVIII fue testigo del desarrollo temprano de la forma literaria dominante de los tiempos modernos, la novela. La novela surgió como una forma con estructura e interacción entre los individuos y sus relaciones con la sociedad. Como nueva forma, la novela tiende a hacer algunas declaraciones importantes, críticas y sociales sobre la sociedad. De ahí que la novela se utilice para crear un nuevo entorno que se relacione con la vida y las personas. De hecho, esto es lo que hace que la novela atraiga a los lectores como un nuevo género. Los novelistas intentan lidiar con los problemas sociales cotidianos que ocurren en la vida de las personas o fingen que están contando historias reales.

No es sorprendente encontrar que Daniel Defoe moldea su Robinson Crusoe (1719) en una historia real, mientras que Samuel Richardson en Pamela (1740) resulta ser didáctico para satisfacer las necesidades del creciente número de lectoras. Por su parte, Henry Fielding intenta exponer su sociedad a los lectores en su obra maestra La historia de Tom Jones, un expósito (1749); a partir de ahora Tom Jones. En consecuencia, la novela se vuelve popular en este momento porque tiene algo relevante para la mafia; se trata de su vida social y pueden identificarse con sus personajes en la vida diaria real. A través de Tom Jones, Fielding presentó "una imagen verdadera y realista de la naturaleza humana" (Kettle, 71). Mientras su principal preocupación sea la sociedad existente, los novelistas se sienten tan involucrados que su crítica se vuelve directa, franca y efectiva. Mi artículo se ocupa de estas preocupaciones tal y como se describen en las novelas mencionadas anteriormente.

Palabras clave: novela; protesta social; Crusoe; Pamela; Tom Jones.

\section{INTRODUCTION}

The early eighteenth century witnessed the development of the dominant literary form of modern times, the novel. Hence, "the novel emerged as a form with tight structure and an interplay between individuals and their relationships to society" (Griffith 62). As a new form, the novel tends to make some significant, critical, and social statements about the society. Hence, the novel is used to create a new environment that is related to people and their life. Novelists either try to deal with daily social problems that happen in the lives of people or pretend that they are telling real stories. According to anonymous article titled, 'Reasons for the rise of the novel in the eighteenth century' in the web blog Naeem Educational Organisation (NEO), the novelists wrote about common people revealing the "the psyche of the middle class" (2010, para.4). Hence, Defoe's Robinson
Crusoe, Richardson's Pamela, and Fielding's Tom Jones were appealing to the readers.

It is not surprising to find that Daniel Defoe pretends that his Moll Flanders is a true story. He also molds his Robinson Crusoe on a real story. Others like Samuel Richardson in Pamela and Fanny Burney in Evelina try to be didactic to meet the needs of the growing numbers of female readers. On his part, Henry Fielding tries to expose his society to the readers in his masterpiece Tom Jones. All this is to make novels as a new form of art more credible or at least acceptable to the public readers, particularly the growing middle class. Indeed, "the industrial revolution [of the $18^{\text {th }} \mathrm{c}$.] ... paved the way to the rise of the middle-class" (Hasan 18). The same thing is confirmed by Choeda who states that "one outcome of industrial revolution was the rise of middle class" (1101). 
Hence, the novel becomes popular at this time because it has something relevant to the mob; it deals with their social life, and they can identify themselves with its characters in the actual daily life. As long as its main concern is the existing society, novelists feel so involved that their criticism becomes direct, frank, and effective. Worth mentioning, Daniel Defoe's Robinson Crusoe and Henry Fielding's Tom Jones are some of early English novels.

$$
* * *
$$

\section{SOCIAL PROTEST AND THE RISE OF THE NOVEL}

Well, as a new form, and since the novel has no preceding traditions, novelists find themselves free to try and indeed explore different forms. For example, Defoe, in his Robinson Crusoe, tries to collect a variety of episodes that have something to do with the hero in a journalistic method. On his part Richardson makes an experiment on a new form, that is the epistolary form in Pamela. Fielding in Tom Jones divides the whole story into books, each of which starts with a critical essay, and uses the prose-epic form. Since novelists are not confined to specific forms, they have the choice to adopt the most appropriate form they think in order to convey their social message. That novelists are not confined with specific forms is a very important reason that makes the novel a more effective form of articulating social protest in my opinion.

In addition to form-freedom, they have enough space to express what they want to say. Language is another factor that makes the novel effective; the novelists usually use the common language to express their opinions - a language, which is preferred and understood by the common people. But how did the novelists manage to express their social protest in their works in the early $18^{\text {th }}$ century?

Both Daniel Defoe and Samuel Richardson belong to the middle class and express in their works middle-class interests and attitudes. They also write about and for women. The development of the novel witnessed at this early period the growing number of female readers. Defoe shows his world not as it should be but as it is, populated with people who are motivated by the practical concerns that dominate their daily lives. It seems that he did not seek readers from the upper class. He was content to interest the middle and lower classes that are already avid readers of tales of adventures and crime.

Daniel Defoe in his novel Robinson Crusoe (1719) presents a hero who longs to go to sea, to seek the extremes of sensation and danger. This novel functions as Defoe's defense of his bourgeois Protestantism. Defoe saw the Tory aristocrats as his adversaries, whose royalism in government and religion stifled middleclass aspirations. The hero's adventures - the shipwrecks, his life in South America, and his isolation on an island - provide Defoe with good materials for his polemic in favor of the middle class. Though Robinson Crusoe's decision to become a sailor is an act of adolescent rebellion, yet it is an act of proving his individuality. At the beginning, "Robinson rejects his father's advice and religious teachings at the beginning of the novel, in order to travel and have some adventure and wealth" (Hasan 20).

As a young man, Crusoe feels it is necessary to test himself, and to discover his own ethic. As a matter of fact, Crusoe's adventures reveal his spiritual conversion, and depict his return to the ethics and religion of his father. After being able to depend on himself during his isolation, and becoming self-reliant, and indeed answering the question of the novel- "Whence are we?"Defoe takes his hero back to his middle-class society - a society that started to have a new political structure at that time. Generally speaking, "Defoe creates a hero and a situation with which every reader can in some sense identify" (Mckenna 107), and we see as events go on that "Crusoe is in control of the products of his labour" (Eagleton 23). 
Generally, Robinson Crusoe might be called the first English novel where Defoe's method is somewhat journalistic; his narratives are always fictional autobiographies pretending to be true. Hence, he created a variety of superbly detailed episodes that deal with the existing middle class and their struggle to live in the aristocratic milieu.

On the other hand, another novelist Samuel Richardson establishes a new form for the novel - the epistolary method. He put to use the journalistic method adapted by Defoe to some extent. The letters in Pamela (1740) are more like detailed journals than models of correspondence. The popularity of this novel comes from the fact that it is didactic; it presents the moral code of the middle class - a class that was trying to have its position in the aristocratic society. It was while he was compiling a little book of model letters that he conceived the idea of Pamela, a story told in a series of letters in which a virtuous servant girl who resists her master's base designs on her virtue eventually wins him as her husband.

The triumph of the middle-class code in sexual ethics brings not only $\mathrm{Mr}$. B-'s marriage proposal, but also his re-education in proper attitudes toward sex and marriage. In Eagleton's words, "Pamela is fairly obviously working for her own elevation, even if only unconsciously" (47).

The movement for social and moral reform, in Pamela, tends to be mainly supported by the middle class. Richardson obviously uses Pamela's values and ethics to expose the implications of Mr. B-'s amoral world of pride and power.

It is through writing Pamela and other novels that Richardson created a fiction that embodied the ideals and the tensions of his society. No earlier author had involved his readers in the thoughts and emotions of his characters as Richardson did. Also, no earlier author had paid such close attention to the pressures on women as he did. Hence, his novel was and is still appreciated by readers who find no other way but either to identify themselves or sympathize with the heroine.

In brief, Richardson is regarded as the originator of the modern English novel and the first writer to fully explore the individual psychology of his characters. Using the epistolary form, Richardson manages to convert readers to accept the reality of his protagonist's maidenly dilemma by placing her in a crisis that is genuine and appropriate to her way of life.

It is Henry Fielding who saw in Richardson's Pamela a misleading image of virtue, and wrote Joseph Andrews as a burlesque of Pamela. But critics consider his great novel The History of Tom Jones, a Foundling (1749) as his masterpiece where the protagonist becomes the pattern of the good-natured hero whose varied social adventures form good context for Fielding to express a clear "view of all levels of English society" (Griffith 65) of his time. According to Mckenna, Tom Jones provides Fielding "with its great comic gusto, vast gallery of characters" a chance to contrast "scenes of high and low life in London and the provinces" (115). He shows a dislike of high society. Tom Jones is an epic but in prose. Fielding's use of prose epic is one of his great contributions to the novel form. Though the novel is crowded with a lot of incidents and with varied types of men and women, yet each episode contributes to the general narrative pattern. Through Tom Jones (1742) Fielding presented "a true and realistic picture of human nature" (Kettle 71).

Tom Jones is indeed a satirical novel aiming at reconstruction of the society in question. Fielding directs great criticism toward the "swarms of pedants" in a reconstructive satirical mode. He delivers strong blows toward his two thinkers: Square and Thwackum. On either side of Squire Allworthy, each appears as a pedant to the other. On every occasion they give opposite justifications for the same morality. On every occasion Square gives a grotesque repetition of 
the same phrases, "the actual fitness of things," "the natural beauty of virtue." Thwackum meets him with the opposite formula, "the divine power of grace," "no religion exists independent of honor." And in that society "Tom is stigmatized as a "bastard" and cannot wed a young lady of her class" (Wikipedia Para. 2)

However, the moral purpose of Tom Jones centers upon a choice an individual has to make between living by instinct and living by prudence and calculation. Tom lives by his natural goodness of heart, whereas Blifil uses reason in the service of hypocrisy. One of the things that I may emphasize here is that the length of the novel gives the author a chance to explore and express his topic thoroughly - a characteristic that is hard to find in other genres. In his prose epic, Fielding has been able to depict human nature. The villain Blifil is unreconstuctedly wicked, but the hero Tom Jones is essentially good, although flawed. Both are born and reared in the same environment, but one is wicked and one is good. Generally, Tom Jones can safely be described as bearing the features of an epic, which mirrors the eighteenth century England. Fielding saw his people as they were and told all he saw.

\section{CONCLUSION}

In conclusion, as a new and rather shapeless literary genre, with little discipline and no classical tradition, the early novelists like Richardson and Fielding try new forms and structures for the novel. There have been no restraints upon the novelists. They manage to invent new forms that convey their social message. In addition, the new forms and content appeal to the new growing middle class readers and accordingly, the effects of these writings are great. Also, the invented forms are taken by the following generations of novelists as models for writing novels. From Richardson, they have taken the epistolary method of story telling. Fielding presents a new critical analysis of the problems he has to tackle through the use of the patterns of the prose epic.

Before Richardson and Fielding, it is Defoe who manages to defend the middle class in his novel Robinson Crusoe and uses the journalistic method in doing so. As long as the novel passes through a period of experimentation, novelists have freedom to choose the best and appropriate form to present the social problems of their societies. Writers of other genres have to follow specific structure and style and address a specific class in the society. Due to these restraints, their writings become less effective form of articulating social protest during this period than the novel.

\section{REFERENCES}

1. Choeda. (2019). The Origin and Development of English Novel: A Descriptive Literature Review. International Journal of English, Literature and Social Science (IJELS) 4(4), 1099-1104. https:// dx.doi.org/10.22161/ijels.4429

2. Defoe, Daniel. (2007). Robinson Crusoe. Oxford University Press.

3. Eagleton, Terry. (2012). The English Novel: An Introduction. Blackwell Publishing Ltd.

4. Fielding, Henry. (1998). The History of Tom Jones, a Foundling. New York :Modern Library.

5. Griffith, Benjamin W. (1991). Study Keys to English Literature. NY: Barron's Educational Series, Inc..

6. Hasan, Mariwan N. (2015). "The Eighteenth Century and the Rise of the English Novel." International Journal of Literature and Arts. 3(2), 18-21. https://dx.doi.org/10.11648/j. ijla.20150302.12

7. Kettle, A (1967). An Introduction to the English Novel. New Delhi: Universal Book Stall.

8. McKenna, Amy. (2009). Ed. The 100 Most Influential Writers of All Time. Chicago: Britannica Educational Publishing. EPUB. https://eb.pdn.ipublishcentral.com/product/100-most-influential- 
writers-all-time

9. Naeem Educational Organisation. (2010). Reasons for the rise of the novel in the eighteenth century [Blog post]. Retrieved from http://neoenglishsystem.blogspot.com/2010/12/reasons-forrise-of-novel-in-eighteenth.html\#more

10. Richardson, Samuel. (2008). Pamela, Or, Virtue Rewarded. Oxford University Press.

11. Thornley, G. C., and Gwyneth Roberts. (1984). An Outline of English Literature. New Ed. Harlow: Longman.

12. Watt, Ian. (1957). The Rise of the Novel: Studies in Defoe, Richardson and Fielding. Berkeley: University of California Press.

13. Wikipedia contributors. (2020). "Tom Jones (1963 film)." Wikipedia, The Free Encyclopedia, 3 Dec. Web. 16 Dec. 2020. 